dose rather than malnutrition in the children. ${ }^{6}$ Vaccination gives substantial protection, reducing child mortality from the age of vaccination by at least $30 \% .^{7} \mathrm{~A}$ big difficulty in many countries is that up to the present measles immunisation cannot be given to children aged under 9 months. The World Health Organisation recommends, however, that in 1990 a high titre of the more immunogenic Edmonston-Zagreb vaccine should be made available. This concentrated vaccine will overcome residual maternal antibodies and may be used at the age of 6 months. ${ }^{8}$ Unicef hopes to have supplies available for sub-Saharan Africa by the middle of 1990 .

What about other new vaccines? All the vaccines available were already in use as long ago as 1974. There are many exciting potentials for the improvement of existing vaccines and new vaccines against major killer diseases, but resources for the development of new vaccines are limited. Many countries allot half of their research resources to the military. Can we hope that a proportion of this could be deflected to research on saving children's lives? Even then, particularly at this time of year, we need to consider the saying, "The difference between children and adults is the size and complexity of the toys they play with." World wide there is an unholy alliance between the developers of adult toys and their manufacturers and the medical profession, and it is this that absorbs so much research money. In Britain we suffer from vociferous pressure groups wanting investment in a $£ 10$ million cyclotron, though there are grave doubts over its medical value and a cost benefit analysis that would be absurd. ${ }^{9}$ Such monetary resources could save the lives of thousands of children.

DAVID MORLEY

Emeritus Professor of Tropical Child Health,

University of London,

Institute of Child Health,

London WCIN 1EH

1 Unicef. State of the world's children. Oxford: Oxford University Press, 1989.

2 Burki SJ, Voorhoeve JJC, Layton R, et al. Global estimates for meeting basic needs. Washington DC: World Bank, 1977 .

3 World Health Organisation. Expanded programme of immunisation. Geneva: World Health Organisation, 1989. (Progress and Evaluation Report A42/10.)

4 World Bank. Sub-Saharan Africa from crisis to sustainable growth. Washington DC: World Bank, 1989.

5 Unicef. State of the world's children. Oxford: Oxford University Press, 1985.

6 Morley DC, Aaby P. Severe measles: a new understanding. Medical Digest 1970;14:4-6.
7 Aaby P, Pedersen IB, Knudsen K, et al. Child mortality related to seroconversion or lack of seroconversion after measles vaccination. Paediatr Infect Dis 1989;8:197-200.

8 Khanum S, Uddin N, Garelick H, Mann G, Tomkins A. Comparison of Edmondston-Zagreb and Schwarz strains of measles vaccines given by aerosol or subcutaneous injection. Lancet 1987; $151-3$.

9 Tobias JS. The cyclotron saga continues. Br Med f 1989;299:1294-5.

\section{On the state of the public health}

\section{Thought provoking and readable-at last}

Most years since 1856 the chief medical officer of the Department of Health has produced an annual report-documents of variable style, content, and value. When Sir Donald Acheson became chief medical officer in 1984 he reviewed past reports, talked to colleagues, and set about making his annual accounts of the nation's health "an unbiased record of topical events relating to health and a commentary on progress and on important unsolved problems."

The latest report achieves these aims and does so in a style that encourages doctors who dip their noses into the pages to read on. ${ }^{2}$ Necessarily, much of the comment deals with events no longer in the headlines - but it is helpful and reassuring to have verdicts on aluminium in drinking water (no cause for immediate concern) and on the risks of listeriosis for the average healthy citizen (very small indeed). There are masses of data on health statistics, including international comparisons that show England and Wales well down the league table for infant mortality but close to the leaders for life expectancy. The report refers repeatedly to geographical variations in disease and mortality within England and Wales but makes little mention of social class differences in adultsyet these are very substantial: the gap between the rich and poor is as wide in health as it is in other more obvious features of lifestyle. Each year Sir Donald has one chapter focused on a particular aspect of health. This year it was the health of children. May we suggest another topic for next year-the health of the poor?

Deputy Editor, $B M \mathcal{F}$

TONY SMITH

1 Department of Health and Social Security. On the state of the public health for the year 1986. London HMSO, 1987.

2 Department of Health and Social Security. On the state of the public health for the year 1988. London: HMSO, 1989.

\section{Pay in the public sector}

\section{More review bodies needed}

The tenacity with which ambulance workers in Britain are pursuing their pay dispute this winter is scarcely surprising: together with several other public sector employees they have had a raw deal under the current administration. Ten years ago the distribution of pay in Britain was much more equal than it is now. In 1979 someone $10 \%$ from the bottom of the pay distribution received around half the pay of someone $10 \%$ from the top. Today that same person on a low wage earns only one third the amount at the top end of the scale. Many public servants have clearly been the losers in such a change.

For most employees in the public sector the 1980s have seen a decline in their pay relative to private earnings - in some cases (teachers, soldiers, and health service ancillaries) aggravating a trend begun in the 1970s. The modest increases in real wages received by these groups look meagre in comparison with those awarded in the private sector.

Wishful thinking by governments cannot ignore the fact that managers in the public sector have to accept influences from the private sector on the pay of their employees. Whether employers cite "labour market" factors as key determinants of pay or unions plead notions of equity, in effect both are arguing on the basis of comparability. And both know that public servants are increasingly losing that race.

For those at the bottom of the public sector pay league it is cold comfort to know that most of them do not fall within any standard definition of low pay: only women employed in the NHS as domestics can claim this dubious distinction. None the less, real wages have been shoved downwards as cash limited NHS managers have held down the pay of manual workers to fund unexpectedly high increases for nurses. Another factor in the NHS and in local government has been the adverse effect on earnings caused by compulsory competitive tendering for certain services. Higher productivity has been demanded, and crucial sources of additional income such as overtime have been removed. In many cases savings have been made - at the expense of filthy hospitals and roads and in the quality of other services.

Not only the less skilled have lost out. Public sector top 
managers have not benefited as much as their private sector counterparts from the widening national spectrum of earnings. This is at the very time that the radical reorganisation of public services requires that top quality managers are hiredand kept - to handle the changes.

\section{Job security}

Until recently public servants could at least console themselves that in terms of non-monetary remuneration they could make up some lost ground with the private sector. "Job security" was a key element-but one that has been undermined by privatisation, competitive tendering, and individual employment contracts based on performance. Other benefits may also be diluted. If self governing hospitals choose to adopt non-Whitley regulations employees will face less favourable terms of employment legislation on issues such as sick pay. Even their lead on less work for less pay is being eroded as private sector employees are given increasing amounts of holiday. And if regionally differentiated pay is introduced the safety net of national wage rates will be removed from those in the lower wage sectors.

Yet not all public employees are in the same boat. Police, firemen, and nurses have received annual increases well above the public sector average thanks to index linked formulas and a review body. The trade off is clear: higher pay and no strikes. So why not offer such alternatives to collective bargaining to ambulance staff and other workers in the public sector? The government's summer enthusiasm for banning public sector strikes, particularly in emergency services, seems to have waned: it would cost the Treasury money. Review bodies cannot provide a total panacea - they cannot handle working practices - but they do take careful account of recruitment and motivation, ensuring decent treatment for public employees without recourse to strike action. It is not only the police and nurses who need a fair deal.

RACHEL BAILEY

Part Time Tutor,

Department of Industrial Relations,

London School of Economics and Political Science,

London WC2A 2AE

\section{Encore fin de siècle}

\section{What will the 1990s bring?}

Centuries, when they move towards their end, impress on human populations the need to imagine that something has got to happen or that something will happen, and soon. Other decades may come and go, but the last in each series cannot just be let pass without notice, without change. And the choice, in modern times, seems stark: degeneration or regeneration? Whatever else happens, the sense of being unhappy with the golden mean, the norm, the life of moyen sensuel, is pervasive. So too is impatience with political normality. Whether seeking to bring liberty to authoritarian regimes, or, more chillingly, to restore repression, the ends of centuries urge self dramatisation.

And for the 1990s two possibilities present themselves: the promise of renewal, of hope, of dawn - as in the 1790s - or the sense of exhaustion, of depletion, of jaded tastes and weary repetition - the 1890 s. Indeed, in the 1890 s a French phrase had to be coined to capture the spirit of the age: fin de siècle. Very little health is evoked by that phrase, few images of strength or ardour. The fin de siècle is metropolitan; it suggests a city scene, a café perhaps, whose denizens in their decadent self absorption have somehow failed to look out of the art nouveau window to see the gathering crowd of tramps and beggars shuffling towards the light, some carrying weapons.

The final decade of the century is the time when the level of human wishes, of human longings, explodes - wishing for the end or the beginning or some strange mixture of the two. Once upon a time the drama would have been scripted by the gods and then by God. His signs would appear: comets, epidemics, strange visitations. Now, alone with its terrible dreams, mankind is trying to write its own script, and only the sense of an ending (that may or may not bring something new) is agreed. Otherwise the script is up for grabs. It took the masterwork of that student of human dreams, Sigmund Freud, to point out how strange the dreams of the human scriptwriter were turning out to be: his Interpretation of Dreams was completed in 1899 and published in 1900 .

\section{Living on the edge}

It is the longing for the strange, the risqué, the sciences of the unknown, that comes to the fore in the fin de siècle. In the 1790 s we saw mesmerism, Jacobinism, terror; in the 1890 s, hypnotism, spiritualism, nihilism. In the 1990s, with the slow breakdown of global ecological balance, the growth area looks like being witchcraft. As the state either abandons its medical responsibilities to its citizens, or gives up any pretence that it can afford to run a service for them, the fringe calls. The ancient Hippocratic paean to the balanced life, the life that picks its careful way between deprivation and excess, is almost deliberately being forgotten. Some of the longings for millennial events get answered: one could hear sighs of satisfaction that the San Francisco earthquake had hit this year, and people presumably want more, not less, of the same. The century's last decade demands a life wish and also a death wish. History decides which it will be.

Medical history, as a branch of general history, can teach only that disease springs from chaos, from imbalance, from pathological social experience. The decadence of societies is probably far better proved by the way they organise the relation between income and health than it is by the kinds of drugs favoured by its various social groupings or their sexual practices. The traditional image of the fin de siècle-of the naughty dancing, the contrived emptiness, the immovability of oppressive political regimes-pales into insignificance beside the daily toll on the bodies of human inhabitants. The extraordinary events in Eastern Europe and the doomy visions of a luxurious but anxiety ridden West both have their price and offer their various hopes and fears. In the 1990s the answers to the problems of living (in whatever sphere) seem unlikely to be sought other than in the extreme, the iconoclastic, the menacing, the anti-Hippocratic, the desperate remedies that flourish as Time forces a choice on humanity.

MICHAEL NEVE

Lecturer in the History of Medicine,

Wellcome Foundation,

London NW 1 2BP 